\title{
BELOTAK: TOWARDS PRESERVING THE TRADITIONAL FOOD OF LENGGONG, PERAK
}

\author{
Munira Saaidin \\ Faculty of Business \& Technology, UNITAR International University, Malaysia \\ Nur Juliana Azhari \\ School of Culinary Arts, UNITAR International University, Malaysia \\ Erdaizzati Mohd Som \\ UNITAR College, UNITAR International University, Malaysia \\ Annis Jamaluddin \\ School of Culinary Arts, UNITAR International University, Malaysia \\ W. Eddie Azlie W. Mohd Asri \\ School of Culinary Arts, UNITAR International University, Malaysia \\ Mislan Nenin \\ Faculty of Business \& Technology, UNITAR International University, Malaysia
}

\begin{abstract}
The purposes of this descriptive study were to identify the traditional foods in the sub-district of Lenggong in the state of Perak, to find out the main ingredients used, to understand the manner in which the ingredients were prepared and cooked, and the way the food is served and the occasion it would be consumed. The overall purpose would be to help preserved the traditional food knowledge. For those purposes, 5 traditional food experts on Belotak were invited from among the community of the area to provide detail feedback on the required information. The findings were very interesting for it had shown the reason why Belotak had become a traditional food and the comprehensive knowledge that the experts had on the dish. The study was able to assemble the detail information on the dish. Additionally, the community members knowledge on the food was gathered via a structured questionnaire and the findings indicated that some distinct difference in the level of knowledge among the 5 age groups, but on the basis of gender there was no difference. Apparently most of them had some knowledge pertaining to the ingredients used and the methods of preparation of Belotak. The study had indicated to some extent on the importance of preserving the traditional food as a culinary heritage of the area.
\end{abstract}


Key words: Belotak, Cultural tradition, Food Knowledge, Culinary heritage.

Cite this Article: Munira Saaidin, Nur Juliana Azhari, Erdaizzati Mohd Som, Annis Jamaluddin, W. Eddie Azlie W. Mohd Asri, Mislan Nenin, Belotak: Towards Preserving the Traditional Food of Lenggong, Perak, International Journal of Management, 11(12), 2020, pp 368-381.

http://iaeme.com/Home/issue/IJM?Volume=11\&Issue $=12$

\section{INTRODUCTION}

Food had always been a part of culture, and tradition food is very often distinctive from one native group to another. Traditional foods played a major role in the traditions of different cultures and regions for thousands of years including foods that had been consumed locally and regionally for an extended time period. Preserving the traditional food would meant preserving the culture, but so often, the traditional food would easily be forgotten by the young generations. The preparation methods of traditional foods were often part of the folklore of a country or a region (CENM- Centre of Excellence in Nutrition and Metabolism). Traditional Food Knowledge (TFK) as contended by Kwik (2008) referred to a cultural tradition of sharing food, recipes and cooking skills and techniques and passing down that collective wisdom through generations. He further stated that the traditional food knowledge could be one means of asserting cultural identity and could be a way to connect people to the natural world.

Food was signified as markers for identity regardless of geographical, social and political differences separating the populations (Md Ramli, Mohd Zahari, Abdul Halim and Mohamed Aris, 2017). Parallel with that notion, Quah (2008) stated that those foods associated with meanings, symbols and expressions and was recognized as the integrative force that enhanced solidarity and alliances between individuals and kin groups. In many multi-cultural countries, to have a commonly accepted food identity in representing the image of a nation had been important especially in term of tradition and authenticity (Md Ramli, Mohd Zahari, Abdul Halim and Mohamed Aris, 2017).

Some ethnic groups were reported not only facing the deskilling issues related to domestic cooking skills, but had begun to lose the traditional food culture due to the inability of the elder generations to pass down the traditional cooking knowledge to the younger generations (Stringer, 2009; Bowen and Devine, 2011).

Based on the research issues, the following questions would be addressed:

- Are there identifiable traditional foods in the study area. If so, what are they?

- What are the main ingredients used in the making of the traditional foods?

- Are there common methods of preparations, cooking and consumption (foodways) of those traditional foods?

- What are the awareness level and the associated level of foodways knowledge on the traditional foods among the youths/community in the study area?

This study addressed the need for the development of knowledge on traditional foods, their origins, the special ingredients, and the specialized methods of preparation. The findings could help in the enhancement of knowledge on the influences of specific state cuisines, the food structures, the traditions and cultures and their perspectives towards the methods of preparation and consumption of traditional foods.

This study aimed at investigating if there were distinct types of the traditional foods in the sub-district of Lenggong in the Hulu Perak District. The specific objectives of the study were to: (1) Identify the traditional foods in area, (2) Examine the basic ingredients of the identified 
traditional foods, (3) Understand the common methods of preparation and cooking of the identified traditional foods, and (4) Determining the level of foodways knowledge on the identified traditional foods amongst the youths/community in the sub-district of Lenggong.

\subsection{Conceptual Framework}

The following conceptual framework depicted the variables examined in this study.

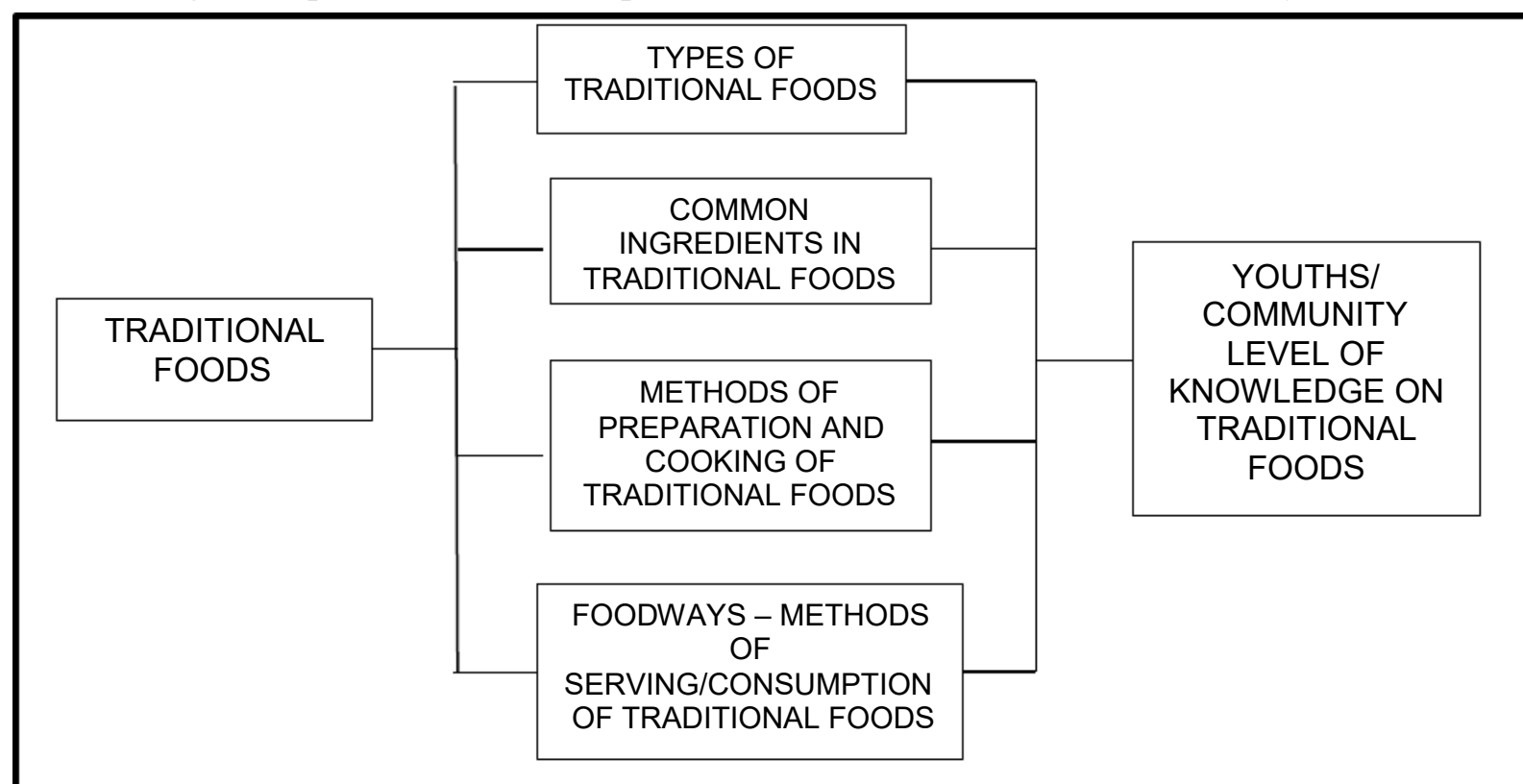

Figure 1 Conceptual Framework

\section{LITERATURE OVERVIEW}

Foods that have been consumed for many generations which includes all indigenous food plants found in that region or locality (European Union, 2007). In other words, traditional foods are those foods originating locally in an area with respect to the country, region, district or sub district (Ohiokpehai, 2003).

Jordana (2000) indicated that traditional foods include foods that have been consumed locally or regionally for an extensive time period. He added that the methods for the preparation of such foods have been passed down through generations and are now part of the folklore of the people. Kristbergsson (2016) indicated that foods and dishes that are passed through generations or which have been consumed by many generations. All traditional foodrelated activities, concepts and beliefs shared by a particular group of people give a meaning to their identity (Gold, 2007).

Traditional food knowledge can provide an individual with the capacity to prepare meals that are nutritious, safe, and culturally relevant (Kwik, 2008). He added that that skill can support adaptation to altered food environments, such as is the case for immigrants and indigenous populations and that there are personal and community benefits to gaining or relearning traditional food knowledge. Such that the community capacity increases with a greater number of skilled practitioners and educated consumers. Information sharing of the cultural life skills engages people from various walks of life as they learn about, and from, each other. Jaffe and Gertler, (2006) indicated that to the immigrant cultures, the maintenance 
of traditional food knowledge is even more important because it provides a self-identifiable cultural bridge between the geography of their past and their present.

In Malaysia, traditional foods such as Lemang, Tempoyak and Rendang Tok were some of the popular traditional dishes which were originally from the state of Perak had spread well across the country. Malay cuisine which had dominated in this region, had also the profound influenced of the Chinese and Indian cuisines. The cuisines of the Hulu Perak District which included the areas of Grik, Lenggong, Pengkalan Hulu and Temenggor were heavily influenced by the Pattani region in the Southern Thai provinces. This had been proven by the existence of traditional dishes such as Kebebe, Air Lawa, and Umbut Bayas, Gulai Umbut Pisang Hutan. They were known as Hulu Perak traditional foods which thus, represented the authenticity of Perak cuisines. But unfortunately, they might become extinct unless some preservation efforts were carried out by the elder generations of the area.

Traditional foods had been an important element of cultural heritage and they played an important role in establishing the local identity and consumer behavior. Additionally, the traditional foods had been very important for rural development and for the sustainability of small and medium size country (Jordana, 2000)

\section{Summary of Concepts and Terms}

\section{Traditional Foods}

Foods that have been consumed for many generations which includes all indigenous food plants found in that region or locality (European Union, 2007). In other words, traditional foods are those foods originating locally in an area with respect to the country, region, district or sub district (Ohiokpehai, 2003).

\section{Traditional Food Knowledge (TFK)}

The cumulative teachings and experience gained from the process of sharing foodways from generation to generation. Traditional food knowledge is a concept which encompasses indigenous and immigrant populations and focuses on the process of learning and sharing (Kwik, 2008).

\section{Foodways}

Principally, foodways is a combination of two words which are 'food' and 'ways' and refers to the way food is prepared, served and consumed by human beings. Simply understood as the preparation and consumption of food (Noriza, Mohd Zahari, Shazali \& Rosmaliza, 2012).

\section{RESEARCH METHODOLOGY}

This study required mixed method, which was the combination of qualitative and quantitative data and information so as to achieve the study objectives. A qualitative approach had been applied through the process of identifying the traditional foods which had been in existence in Hulu Perak District. This approach would also help to better understand the process of preparation and consumption (foodways) of the identified traditional foods. The information gathered through this approach would provide a further understanding of the process and the reasons for such perceptions.

The quantitative approach had also being used through the process of examining the level of foodways knowledge on the identified traditional foods amongst the youth of Hulu Perak District. It was deemed as the most appropriate method that could provide feedback in a concise manner and also and an economical way of collecting a large amount of data (Krathwohl,1998). However, for this study a small sample of 46 youths was used. 
The selected are of study was the subdistrict of Lenggong, in the district of Hulu Perak. The Hulu Perak District is a district in the state of Perak, Malaysia. To the east of the district is the state of Kelantan, to the west is Kedah, to the south is the district of Kuala Kangsar, while to the south-west is the district of Larut, Matang and Selama. Hulu Perak also shares a border with Betong District of Thailand. The area covers about 6,560 sq. kilometers. The major ethnic groups of the area were the Malays, and the Indigenous people or Orang Asli. The Malaysian Chinese and Malaysian Indians comprised of a very small percentage of the population.

There are two groups of respondents in this study:

\section{Group 1: Five (5) Traditional Food Experts}

Process of selecting the food experts: (1) A focus group which comprised of 7 prominent individuals from the Hulu Perak district was asked on the popular traditional food of the area, (2) The head of communities of Hulu Perak were contacted and were requested to recommend a few names of the traditional food experts in their communities, (3) All prospective traditional food experts were contacted via telephone for permission to conduct the interviews and the convenient date, times, and venues for the interviews, (4) All traditional food experts (which may include traditional food restaurants owners, food traditional entrepreneurs, chefs, cooks and selected senior citizens of the district) were asked to name all the traditional foods, and from that list and (5) Among the traditional food experts, 5 experts were finally selected based on the positive responses on the traditional foods.

Group 2: Forty-six (46) Respondents (youths) on the questionnaires

Process of selecting the youth respondents: (1) Characteristics: those youths aged between 18 and 40 years and those 50 and over, (2) Initial question asked: Can you name all the traditional foods showed? Those who could not name any was eliminated from the list, (3) Questionnaires were then distributed to those who answered affirmatively.

Primary Data was collected via Face-to-face discussions and with the selected traditional food experts. The discussions and interviews were conducted with the guide of a set of semi structured, open-ended questions that were developed to derive significant information on the identified traditional foods. Information were collected via observations on the preparation and cooking of the traditional food by the experts.

A self-administered, structured questionnaire were distributed to the youths/community in the area of Hulu Perak. The questionnaire was aimed at finding out the demographic profiles of the respondents, their overall level of knowledge on traditional foods, and their level of knowledge on the 3 traditional foods of Hulu Perak.

A 5-point Likert-like scale was used to measure the extent of the respondent knowledge on the Traditional Food.

Table 1

\begin{tabular}{|c|c|c|c|c|}
\hline Strongly Disagree & Disagree & Slightly Disagree & Agree & Strongly Agree \\
\hline 1 & 2 & 3 & 4 & 5 \\
\hline
\end{tabular}

The following scale was used to determine the summary of findings on the overall level of knowledge and the specific knowledge on the 3 traditional foods:

Table 2

\begin{tabular}{|l|l|l|l|l|}
\hline \multicolumn{1}{|c|}{$\begin{array}{c}\text { Strongly } \\
\text { Disagree }\end{array}$} & \multicolumn{1}{c|}{ Disagree } & \multicolumn{1}{c|}{$\begin{array}{c}\text { Slightly } \\
\text { Disagree }\end{array}$} & \multicolumn{1}{c|}{ Agree } & \multicolumn{1}{c|}{$\begin{array}{c}\text { Strongly } \\
\text { Agree }\end{array}$} \\
\hline No Knowledge & $\begin{array}{l}\text { Hardly Any } \\
\text { Knowledge }\end{array}$ & $\begin{array}{l}\text { Slight } \\
\text { Knowledge }\end{array}$ & $\begin{array}{l}\text { Partial (Some) } \\
\text { Knowledge }\end{array}$ & $\begin{array}{l}\text { Full } \\
\text { Knowledge }\end{array}$ \\
\hline $1.00-1.99$ & $2.00-2.99$ & $3.00-3.99$ & $4.00-4.99$ & 5.00 \\
\hline
\end{tabular}


The following 8 open-ended questions were directed at the 5 traditional foods experts. The purpose of each question was to derive a consensus on the responses.

Table 3

\begin{tabular}{|c|l|}
\hline $\begin{array}{c}\text { Question } \\
\text { No. }\end{array}$ & \\
\hline 1 & Items \\
\hline 2 & What are the main ingredients to prepare the product? \\
\hline 3 & What is the equipment used to prepare the product? \\
\hline 4 & Where the product originate from? \\
\hline 5 & In what occasion the product will be served to the guests? \\
\hline 6 & To whom the food is prepared? Why? \\
\hline 7 & How the food is served to the guest? \\
\hline 8 & What the other foods can be served with the product? \\
\hline
\end{tabular}

\section{STUDY FINDINGS}

The study findings are presented in two parts:

- Detail on the aspects of Belotak and

- Level of Knowledge on Belotak as a Traditional Food by the community in the Lenggong area.

\subsection{Detail on Belotak as a Traditional Food}

The findings were based on responses on the 8-items as indicated in the instrument used.

FACTOR 1: The main ingredients used in the preparation of Belotak

In respond to the question, all experts shared the same idea that only rotten freshwater fish should be used in making a good Belotak. Due to their availability, ikan Kelaba, ikan Baung, ikan Keli, ikan Tenggalan, ikan Sebara, ikan Batu Bulu, ikan Loma, ikan Sebarau, ikan Belida, and ikan puyu would be used as the main ingredients. In addition, a combination of leaves and shoots namely kadok shoots / leaves, bebuas shoots / leaves, Vietnamese coriander typically obtained from the forest nearby were being used to eliminate the smell that came from the rotten fish, apart from other ingredients to enhance the flavor of Belotak such as lemongrass, young galangal, shallots / red onion, salt, shrimp paste, bird eyes chillies, dried chillies, fresh turmeric / turmeric powder, thick coconut milk dried tamarind, fried grated coconut and asam belimbing. Typically, all Belotak's ingredients were derived from natural plant resources throughout the Lenggong area.

\section{Main Ingredients in the Preparation of Belotak}

Loma Fish

Thick Coconut milk

Dried tamarind

Turmeric powder

Lemongrass

Wild pepper leaves

Bebuas leaves

Shallot

Vietnamese coriander bruised and finely sliced

finely sliced

finely sliced

peeled and finely sliced

sliced 
Torch ginger flower

sliced diagonally

Bird's eye chilies

\section{Seasoning, Salt}

Table 4 indicated the detailed responses by the 5 experts on Belotak.and on the common ingredients used in making of Kebebe:

Table 4 Main Ingredients in Belotak

\begin{tabular}{|l|l|}
\hline Expert 1 & $\begin{array}{l}\text { lemongrass, young galangal, freshwater fish like ikan Kelaba, ikan Baung, ikan } \\
\text { Keli, ikan Tenggalan, ikan Sebara, ikan Batu Bulu, ikan Loma (not a main } \\
\text { preference as it has many bones), shallots, salt, shrimp paste, bird eyes chillies, } \\
\text { dried chillies, fresh turmeric, kadok hoots, bebuas shoots, Vietnamese coriander, } \\
\text { thick coconut milk asam belimbing" }\end{array}$ \\
\hline Expert 2 & $\begin{array}{l}\text { Freshwater fish (ikan Sebarau), lemongrass, fresh turmeric (taste much better) or } \\
\text { turmeric powder, thick coconut milk, dried tamarind, fried grated coconut, } \\
\text { Vietnamese coriander, bebuas leaves (obtained from forest), shallots. }\end{array}$ \\
\hline Expert 3 & $\begin{array}{l}\text { Rotten fish (ikan Belida, ikan Tenggalan), coconut milk,lemongrass, , bebuas } \\
\text { leaves (to remove the stinky smell),shrimp paste, kadok shoots,galangal, red } \\
\text { onion / shallots,Vietnamese coriander, turmeric. }\end{array}$ \\
\hline Expert 4 & $\begin{array}{l}\text { "Rotten fish (use its flesh only), kadok shoots, bebuas leaves (to remove the } \\
\text { stinky smell)." }\end{array}$ \\
\hline Expert 5 & $\begin{array}{l}\text { Freshwater fish like ikan Puyu, ikan Keli (those already went through a rotten } \\
\text { process),shrimp paste (to increase the flavour of Belotak),lemongrass,Vietnamese } \\
\text { coriander, bebuas leaves, kadok leaves. }\end{array}$ \\
\hline
\end{tabular}

FACTOR 2: The methods in which Belotak is being prepared and the reasons for preparing that way

In tracking the experts' experiences, the process of making Belotak should start from trapping the fish and letting them rot naturally. Clean the fish, removed all scales, internal organs and boil in water with dried tamarind. Those fishes needed to be cool off before removing their bone as making Belotak would only require the fish flesh. Meanwhile, the fish heads needed to be blend with water. Pounded the hawas (turmeric, bird eyes chillies, dried chillies), heat them in a pan. In addition, thick coconut milk, salt, shrimp paste would be added together with finely stripped cut leaves, the fish flesh, bebuas shoots / leaves, turmeric leaves / shoots, kadok shoots / leaves, Vietnamese coriander, fresh turmeric, torch ginger flower, dried tamarind and asam belimbing (to cut and removed its pith). It should always be stir and cooked until dry until the color of Belotak resembled the color of meat floss

\section{Methods of Cooking:}

- Rinse Loma fish with dried tamarind and salt, dried outside for one day or until it completely rotten and smelled. Rotten Loma fish should not be refrigerated. Once rotten, Then only it could be poached and debone.

- Combine ingredient A in a saucepan.

- Season with salt and turmeric powder. Mix well.

- Add Loma fish and coconut milk in sequence slowly and progressively, blend well.

- Simmer all ingredients over medium heat or until fragrant, stirring constantly. Serve hot. 
Munira Saaidin, Nur Juliana Azhari, Erdaizzati Mohd Som, Annis Jamaluddin, W. Eddie Azlie W. Mohd Asri, Mislan Nenin

Table 5 indicated the methods in which Belotak is prepared by each of the 5 experts:

Table 5 Methods of Preparation of Belotak

\begin{tabular}{|c|c|}
\hline Expert 1 & $\begin{array}{l}\text { 1. Boiled the water together with dried tamarind. } \\
\text { 2. Add in the rotten fish 3.boiled together with dried tamarind. 4.Let it cool and use only } \\
\text { the flesh (only use fish that has been cut open and removed the internal organ). 4.fish } \\
\text { heads need to be blend with water. } \\
\text { 3. Pounded the hawas (turmeric, bird eyes chillies, dried chillies (blend)) } \\
\text { 4. Heat it on a pan. A pan should be use instead of a pot as the tendency that Belotak } \\
\text { getting burn is quite high. 6. 6. Needs to be stirred always. } \\
\text { 5. Add in thick coconut milk, salt, shrimp paste and let it boil. } \\
\text { 6. Add in together with finely stripped cut leaves and the fish flesh. Bebuas shoots (can be } \\
\text { used a lot in order to eliminate the fishy smell), turmeric leaf shoots, kadok shoots (can } \\
\text { be used a lot in order to eliminate the fishy smell), Vietnamese coriander (can be used a } \\
\text { lot in order to eliminate the fishy smell), 9.Torch ginger flower (bunga kantan) (can be } \\
\text { use according to individual preferences but might cause gassy and nerves pain), } \\
\text { 7. Assam belimbing (to cut and removed its pith). } \\
\text { 8. Cook up until dry (color of belotak should resembles the color of meat floss). "Good } \\
\text { fish produce delicious Belotak and thus saltwater fish is not suitable in making it. In } \\
\text { fact, rotten fish being used in order to differentiate from Masak Lemak if fresh fish } \\
\text { were to be use." }\end{array}$ \\
\hline Expert 2 & $\begin{array}{l}\text { 1. Boiled the fish (it needs to be clean first, cut open, removed internal organ and scales, } \\
\text { leave it for one night) with plain water in a pot and removed the bone. Preferably dead } \\
\text { and rotten fish where the fish need to be kept in chiller after cleaning process before } \\
\text { keeping it for one night. } \\
\text { 2. Mix all ingredients. } \\
\text { 3. Add in thick coconut milk, fresh turmeric, dried tamarind, and salt. } \\
\text { 4. Cook until moist and to taste. }\end{array}$ \\
\hline Expert 3 & $\begin{array}{l}\text { 1. Fish were trapped in a fish trap and let it rotten. } \\
\text { 2. Clean, boiled, removed all the bones } \\
\text { 3. Add coconut milk. } \\
\text { 4. Add other ingredients will be adding in and being cook to almost dry but still moist. } \\
\text { 5. Can be consumed with rice. }\end{array}$ \\
\hline Expert 4 & $\begin{array}{l}\text { "It is yellow in colour and black when it is in a dry state (like a floss). The fish flesh should } \\
\text { be minced and not chunk." } \\
\text { "Previously, peoples won't throw away the rotten fish. Instead, they find other ingredients } \\
\text { to mix with it in order to remove the bad smell. They will go for trawling in the afternoon } \\
\text { and the fish that they caught will be left up until the next morning where they already } \\
\text { bloated. Then, those fish will be placed on the head of small boat until noon for rotting. } \\
\text { This process is a controlling wastage process as non-fresh fish can be consumed too. } \\
\text { Basically, larger fish had been eaten partly by animals like softshell turtles or beaver where } \\
\text { the other half that are in good condition will be using to make Belotak." }\end{array}$ \\
\hline Expert 5 & $\begin{array}{l}\text { 1. Rotten fish should be use. Even though it is a fresh fish, it still needs to go through a } \\
\text { rotting process. In identifying a rotten fish, the flesh should be soft and not firm as } \\
\text { fresh fish. Rotten fish were obtained from the paddy field where it is purposely being } \\
\text { left on the paddy boundaries for the rotting process until noon where those farmers } \\
\text { ending up their ploughing job. There are some peoples who just leave those fish under } \\
\text { the sun or high on the bamboo to prevent from flies. } \\
\text { 2. Clean those fish, removed all scales, internal organs and being boiled, later the bone } \\
\text { will be taken off. } \\
\text { 3. Boiling process is for the separation of bone and flesh where it will be put on tray to } \\
\text { remove it. } \\
\text { 4. Mix all on the pan, pot } \\
\text { 5. Cook / stir until partly moist and dry. Ikan Belida has many fine bones where ikan } \\
\text { Kaloi has bigger bones. The challenge is to remove the bones from ikan Belida. } \\
\text { 6. With all ingredients been mix up including tamarind and salt, it is just nice to provide } \\
\text { flavorful and tasty Belotak. Unfortunately, fresh fish is not suitable for making Belotak } \\
\text { where it is only suitable for Masak Lemak." }\end{array}$ \\
\hline
\end{tabular}


FACTOR 3: The equipment used to prepare Belotak.

\section{Tools/Utensils used in making the Belatok}

In answering the question, the experts mentioned that they needed a pan together with ladle for stirring. This would be a better option for making Belotak compared to pot which would had a tendency of the Belotak getting burn is quite high. Fish traps were used in catching those fishes before the rotting process begin.

Table 6 listed the equipment that were used to make Belotak by the 5 experts:

Table 6 Equipment/Tools used in Preparing Belotak

\begin{tabular}{|l|l|}
\hline Expert 1 & $\begin{array}{l}\text { A pan should be used instead of a pot as the tendency of Belotak getting burn } \\
\text { is quite high. But make sure to always stir the Belotak." }\end{array}$ \\
\hline Expert 2 & A pot or pan and a ladle \\
\hline Expert 3 & $\begin{array}{l}\text { A pan is much easier. } \\
\text { Pot can be used too. Belotak should be cook to almost dry but still contain } \\
\text { moist." }\end{array}$ \\
\hline Expert 4 & No information provided \\
\hline Expert 5 & Fish trap to trap the fish \\
\hline
\end{tabular}

FACTOR 4: The origin of Belotak

\section{Origin of Belotak}

This question tracked the origin of Belotak. Similar viewed were given by the experts during the interview session where Belotak was believed to originate from Patani since the Lenggong area were under the control of Patani. Perhaps, the Belotak recipe was created in preventing wastage of rotten fish. The knowledge had been transferred from one generation to another up until today and the authenticity of the recipe had been well preserved.

The 5 Belotak food experts indicated where Belotak originated from in Table 4.

Table 7 Origin of Belotak

\begin{tabular}{|l|l|}
\hline Expert 1 & - Pattani and was hereditary from my mother, Hajjah Rahmah. \\
\hline Expert 2 & - From great grandparents' era.” \\
\hline Expert 3 & - Pattani. \\
\hline Expert 4 & - Pattani. \\
\hline Expert 5 & -No information provided \\
\hline
\end{tabular}

FACTOR 5: The occasion Belotak would be served to the guests

The 5 experts were asked on the specific occasions when Belotak would be served

\section{Occasions when Belotak is served}

Foods and festivals are synonym with each other where festivals were usually, associated with foods. But Belotak according to the food experts would be made not for any festivals but also for own family consumption. According to them, it was difficult to make Belotak because of the limited supplies of rotten fish and the time constraints. 
In Table 8 the food experts indicated the popular occasions when Belotak is served.

Table 8 Occasion Belotak will be served to the Guests

\begin{tabular}{|l|l|}
\hline Expert 1 & $\begin{array}{l}\text { "It can be consumed at any time, normally with family. } \\
\text { It is not for any festive as it is only requiring the fish flesh." }\end{array}$ \\
\hline Expert 2 & $\begin{array}{l}\text { "We made it when we feel like eating it and not for any feast due to limitation } \\
\text { supplies of rotten fish." }\end{array}$ \\
\hline Expert 3 & No Information \\
\hline Expert 4 & Consume anytime, not limited to certain occasion \\
\hline Expert 5 & $\begin{array}{l}\text { "Only for family on consumption, not for any feast due to the difficulty of } \\
\text { making it." }\end{array}$ \\
\hline
\end{tabular}

FACTOR 6: For whom Belotak is prepared and the reasons for the preparation

The 5 food experts were asked for whom Belotak is usually prepared and the reasons for preparing the dish

\section{Who prepare the Belotak and for who}

In respond to the question, most of the experts stated that Belotak was only suitable for family consumption because of the limited supply of rotten fish.

Table 9 indicated for whom Belotak would be prepared for, and they were:

Table 9 For whom and Reasons for Preparing Belotak

\begin{tabular}{|l|l|}
\hline Expert 1 & No information provided. \\
\hline Expert 2 & It is one of our family meals \\
\hline Expert 3 & $\begin{array}{l}\text { It is unusual and not practical to serve belotak in any occasion here. It's purely } \\
\text { for family consumption }\end{array}$ \\
\hline Expert 4 & No information provided \\
\hline Expert 5 & $\begin{array}{l}\text { Only serve belotak for family consumption (Well processing belotak requires } \\
\text { much effort, nowadays it is quite hard to find rotten fish). }\end{array}$ \\
\hline
\end{tabular}

FACTOR 7: The ways Belotak is served to the guest

The experts were asked to indicate the manner in which Belotak would be served.

\section{Manner in which the food is served}

In respond to the question, based on the experts, the majority of experts mentioned that Belotak would usually be served by using plates.

Table 10 showed the similarities and differences in the responses

Table 10 How Belotak is served

\begin{tabular}{|l|l|}
\hline Expert 1 & No information provided. \\
\hline Expert 2 & Commonly use plate to serve belotak \\
\hline Expert 3 & Usually plates \\
\hline Expert 4 & No information provided \\
\hline Expert 5 & $\begin{array}{l}\text { In olden days, we serve belotak in tin plate. But it is more common to use plate } \\
\text { nowadays. }\end{array}$ \\
\hline
\end{tabular}


FACTOR 8: Other foods can be served with Belotak

The food respondents were asked yo specify the other foods that could be served with Belotak.

\section{Other foods can be served with Belotak}

In respond to the question, all experts shared the same opinion that Belotak could be consumed with cooked rice and glutinous rice since Belotak used freshwater fish such as ikan Kelaba, ikan Baung, ikan Keli, ikan Tenggalan, ikan Sebara, ikan Batu Bulu, ikan Loma, ikan Sebarau, ikan Belida, and ikan puyu as the main ingredients.

The responses were indicated in Table 11

Table 11 Other Foods that are served together with Belotak

\begin{tabular}{|l|l|}
\hline Expert 1 & "Can eat together with cooked rice or glutinous rice". \\
\hline Expert 2 & "Can eat with cooked rice only." \\
\hline Expert 3 & "Can eat with cooked rice." \\
\hline Expert 4 & No information provided \\
\hline Expert 5 & "Can eat with cooked rice." \\
\hline
\end{tabular}

\subsection{Level of Knowledge on Belotak as a Traditional Food by the community in the Lenggong area}

\subsubsection{The findings were based on gender of the community in Lenggong area.}

Partitioning of Gender with Level of Knowledge on Belotak as the Traditional Food of Hulu Perak

On the partitioning of gender with level of knowledge on Belotak as the traditional food of Hulu Perak, all the male and female respondents indicated that had some knowledge pertaining to the 5 questions on whether they knew that (1) the idea for making the Belotak arose when workers saw massive amount of fish being left on the paddy field bunds to rot, (2) some of the selected fish used in the preparation of Belotak were the haruan, catfish and puyu, (3) the selected fish would be clean with the bebuas leaves to eliminate the smell and also to disintegrate the flesh, (4) the side ingredients used in making Belotak were chilies, shallots and lemon grass which were pounded until they became a paste; and the turmeric leaves which were thinly shredded, and that (5) Belotak was an appropriate accompaniment for glutinous rice, rice, and lemang. Thus overall, all the 46 respondents indicated, as shown in Table 12, that they had some knowledge on those 5 aspects on Belotak.

Table 12 Partitioning of Gender with Level of Knowledge on BELOTAK as the Traditional Food

\begin{tabular}{|c|c|c|c|}
\hline \multirow[t]{2}{*}{ NO. } & \multirow[t]{2}{*}{ STATEMENT } & \multicolumn{2}{|c|}{ AVERAGE SCORES } \\
\hline & & $\begin{array}{c}\text { Male } \\
\text { (19 Resp) }\end{array}$ & $\begin{array}{c}\text { Female } \\
(27 \text { Resp) }\end{array}$ \\
\hline 1 & $\begin{array}{l}\text { The idea for making the Belotak arises when workers saw massive amount of } \\
\text { fish being left on the paddy field bunds to rot }\end{array}$ & $\begin{array}{l}\text { Some } \\
\text { K'ledge } \\
4.61\end{array}$ & $\begin{array}{l}\text { Some } \\
\text { K'ledge } \\
4.56\end{array}$ \\
\hline 2 & $\begin{array}{l}\text { Some of the selected fish use in the preparation of Belotak are the haruan, } \\
\text { catfish and puyu. }\end{array}$ & $\begin{array}{l}\text { Some } \\
\text { K'ledge } \\
4.54\end{array}$ & $\begin{array}{l}\text { Some } \\
\text { K'ledge } \\
4.19\end{array}$ \\
\hline 3 & $\begin{array}{l}\text { The selected fish will be clean with the bebuas leaves to eliminate the smell and } \\
\text { also to disintegrate the flesh }\end{array}$ & $\begin{array}{l}\text { Some } \\
\text { K'ledge } \\
4.69\end{array}$ & $\begin{array}{l}\text { Some } \\
\text { K'ledge } \\
4.15\end{array}$ \\
\hline 4 & $\begin{array}{l}\text { The side ingredients use in making Belotak are chilies, shallots and lemon grass } \\
\text { which are pounded until it become a paste; and the turmeric leaves which are } \\
\text { thinly shredded }\end{array}$ & $\begin{array}{c}\text { Some } \\
\text { K'ledge } \\
4.54\end{array}$ & $\begin{array}{c}\text { Some } \\
\text { K'ledge } \\
4.48\end{array}$ \\
\hline 5 & Belotak is an appropriate accompaniment for glutinous rice, rice, and lemang. & $\begin{array}{c}\text { Some } \\
\text { K'ledge } \\
4.62\end{array}$ & $\begin{array}{c}\text { Some } \\
\text { K'ledge } \\
4.63\end{array}$ \\
\hline
\end{tabular}




\subsubsection{The findings were based on age of the community in Lenggong area}

\section{Partitioning of Age Category with Level of Knowledge on BELOTAK as the Traditional Food} of Hulu Perak

Table 13 showed the partitioning of age category with level of knowledge on Belotak as the traditional food of Hulu Perak. The findings indicated that those respondents in two age groups which were those in the 18 to 24 and those of 50 or over years old, all stated that they had some knowledge with pertaining to their knowledge on that (1) the idea for making the Belotak arose when workers saw massive amount of fish being left on the paddy field bunds to rot, (2) some of the selected fish used in the preparation of Belotak were the haruan, catfish and puyu, (3) the selected fish would be cleaned with the bebuas leaves to eliminate the smell and also to disintegrate the flesh, (4) the side ingredients used in making Belotak were chilies, shallots and lemon grass which were pounded until they became a paste; and the turmeric leaves which were thinly shredded, and that (5) Belotak was an appropriate accompaniment for glutinous rice, rice, and lemang.

In contrast, those respondents in the age category of 30 to 39 years old had full knowledge on all the five aspects.

Those in the age category of from 40 to 49 years old, indicated that they had full knowledge that the Belotak was an appropriate accompaniment for glutinous rice, rice, and lemang. On the 4 other aspects that had some knowledge on them.

Those respondents in the age category of 25 to 29 years indicated mixed results. They had full knowledge on the idea that for making the Belotak arose when workers saw massive amount of fish being left on the paddy field bunds to rot, that selected fish would be clean with the bebuas leaves to eliminate the smell and also to disintegrate the flesh, and that the side ingredients used in making Belotak were chilies, shallots and lemon grass which were pounded until they became a paste; and the turmeric leaves which were thinly shredded. On the other two aspects pertaining to the fact that some of the selected fish used in the preparation of Belotak were the haruan, catfish and puyu, and that the Belotak was an appropriate accompaniment for glutinous rice, rice, and lemang.

Table 13 Partitioning of Age Category with Level of Knowledge on BELOTAK as the Traditional Food

\begin{tabular}{|c|c|c|c|c|c|c|}
\hline \multirow[b]{2}{*}{ NO. } & \multirow[b]{2}{*}{ STATEMENT } & \multicolumn{5}{|c|}{ AVERAGE SCORES } \\
\hline & & $\begin{array}{c}\text { 18-24 } \\
\text { (3 Resp) }\end{array}$ & $\begin{array}{c}25-29 \\
\text { (3 Resp) }\end{array}$ & $\begin{array}{c}\text { 30-39 } \\
\text { (2 Resp) }\end{array}$ & $\begin{array}{c}40-49 \\
(17 \\
\text { Resp) }\end{array}$ & $\begin{array}{c}50+(21 \\
\text { Resp })\end{array}$ \\
\hline 1 & $\begin{array}{l}\text { The idea for making the Belotak arises when } \\
\text { workers saw massive amount of fish being } \\
\text { left on the paddy field bunds to rot }\end{array}$ & $\begin{array}{l}\text { Some } \\
\text { K'ledge } \\
4.25\end{array}$ & $\begin{array}{l}\text { Full } \\
\text { K'ledge } \\
5.00\end{array}$ & $\begin{array}{l}\text { Full } \\
\text { K'ledge } \\
5.00\end{array}$ & $\begin{array}{l}\text { Some } \\
\text { K'ledge } \\
4.75\end{array}$ & $\begin{array}{c}\text { Some } \\
\text { K'ledge } \\
4.35\end{array}$ \\
\hline 2 & $\begin{array}{l}\text { Some of the selected fish use in the } \\
\text { preparation of Belotak are the haruan, catfish } \\
\text { and puyu. }\end{array}$ & $\begin{array}{c}\text { Some } \\
\text { K'ledge } \\
4.25\end{array}$ & $\begin{array}{c}\text { Some } \\
\text { K'ledge } \\
3.75\end{array}$ & $\begin{array}{c}\text { Full } \\
\text { K'ledge } \\
5.00\end{array}$ & $\begin{array}{c}\text { Some } \\
\text { K'ledge } \\
4.63\end{array}$ & $\begin{array}{c}\text { Some } \\
\text { K'ledge } \\
4.55 \\
\end{array}$ \\
\hline 3 & $\begin{array}{l}\text { The selected fish will be clean with the } \\
\text { bebuas leaves to eliminate the smell and also } \\
\text { to disintegrate the flesh }\end{array}$ & $\begin{array}{c}\text { Some } \\
\text { K'ledge } \\
4.25 \\
\end{array}$ & $\begin{array}{c}\text { Full } \\
\text { K'ledge } \\
5.00 \\
\end{array}$ & $\begin{array}{c}\text { Full } \\
\text { K'ledge } \\
5.00 \\
\end{array}$ & $\begin{array}{c}\text { Some } \\
\text { K'ledge } \\
4.88\end{array}$ & $\begin{array}{c}\text { Some } \\
\text { K'ledge } \\
4.30 \\
\end{array}$ \\
\hline 4 & $\begin{array}{l}\text { The side ingredients use in making Belotak } \\
\text { are chilies, shallots and lemon grass which } \\
\text { are pounded until it become a paste; and the } \\
\text { turmeric leaves which are thinly shredded }\end{array}$ & $\begin{array}{l}\text { Some } \\
\text { K'ledge } \\
4.25\end{array}$ & $\begin{array}{l}\text { Full } \\
\text { K'ledge } \\
5.00\end{array}$ & $\begin{array}{l}\text { Full } \\
\text { K'ledge } \\
5.00\end{array}$ & $\begin{array}{l}\text { Some } \\
\text { K'ledge } \\
4.38\end{array}$ & $\begin{array}{l}\text { Some } \\
\text { K'ledge } \\
4.25\end{array}$ \\
\hline 5 & $\begin{array}{l}\text { Belotak is an appropriate accompaniment for } \\
\text { glutinous rice, rice, and lemang. }\end{array}$ & $\begin{array}{c}\text { Some } \\
\text { K'ledge } \\
4.50 \\
\end{array}$ & $\begin{array}{c}\text { Some } \\
\text { K'ledge } \\
4.50 \\
\end{array}$ & $\begin{array}{c}\text { Full } \\
\text { K'ledge } \\
5.00 \\
\end{array}$ & $\begin{array}{c}\text { Full } \\
\text { K'ledge } \\
5.00 \\
\end{array}$ & $\begin{array}{c}\text { Some } \\
\text { K'ledge } \\
4.45 \\
\end{array}$ \\
\hline
\end{tabular}




\section{SUMMARY AND CONCLUSIONS}

There four objectives for this study were to identify the traditional foods in area of study which was the Hulu Perak District, to examine the basic ingredients of the identified traditional foods, to understand the common methods of preparation and cooking of the identified traditional foods in Hulu Perak District and to determining the level of foodways knowledge on the identified traditional foods amongst the youths in the Hulu Perak District.

The process of identifying the traditional foods of Hulu Perak was through a focus group which comprised of 7 prominent individuals from the Hulu Perak district who were asked on the popular traditional food of the area. The list of traditional food was derived, and upon the consensus among the members of the focus group and one of the traditional food identified was Belotak. The basic ingredients for Belotak, were identified by the 5 food experts. The common methods of preparation and cooking were also identified on a consensus basis by the 5 traditional food experts. The foodways which referred to the way food the is prepared, served and consumed had also been clearly discussed.

Overall, there was an insignificant difference on the level of knowledge on Belotak as a traditional food between the male and female respondents and between the different age groups. On Belotak, there was an insignificant difference on the level of knowledge between the male and female respondents.

The exploration and findings on Belotak as a traditional food in Hulu Perak could add towards enriching the variety of tourism products of Hulu Perak and to the state of Perak as a whole. It could be used as a reference to generate ideas, innovations and business opportunities for the community. Findings from the study could help to ensure that the knowledge on Belotak as a traditional food could be shared with those interested in the information.

\section{REFERENCES}

[1] Bowen, R. L., \& Devine, C. M. (2011). "Watching a person who knows how to cook, you'll learn a lot".Linked lives, cultural transmission, and the food choices of Puerto Rican girls. [Research Support, Non-U.S. Gov't]. Appetite, 56(2), 290-298.

[2] CENM: Centre of Excellence in Nutrition and Metabolism

[3] European Union. (2007). European Research on Traditional Foods. Belgium: Publications.europa.eu.

[4] Gold, A. L. (2007). Changing Foodways: Generational Communication in a New American Refugee Population. North Dakota State University. North Dakota.

[5] Jaffe, J., Gertler, M. Victual Vicissitudes: Consumer Deskilling and the (Gendered) Transformation of Food Systems. Agric Hum Values 23, 143-162 (2006).

[6] Jordana (2000) Traditional foods: challenges facing the European food industry Food Research International Volume 33, Issues 3-4, April 2000, Pages 147-152

[7] Krathwohl, D. R. (1998). Methods of educational and social science research: An integrated approach (2nd. ed.). New York: Longman.

[8] Kristbergsson (2016) Functional Properties of Traditional Foods. Integrating Food Science and Engineering Knowledge: Into the Food Chain. Publication: Springer Science+Business Media New York. ISBN 978-1-4899-7660-4.

[9] Kwik, J. (2008). Traditional Food Knowledge: A Case Study of an Immigrant Canadian "Foodscape". Environments Journal Volume, 36(1), 59-74. 
Munira Saaidin, Nur Juliana Azhari, Erdaizzati Mohd Som, Annis Jamaluddin, W. Eddie Azlie W. Mohd Asri, Mislan Nenin

[10] Md Ramli, A., Mohd Zahari, M. S., Abdul Halim, N. \& Mohamed Aris, M. H. (2017). Knowledge on the Malaysian Food Heritage. Asian Journal of Quality of Life, AJOOL, 2(5), $31-42$.

[11] Noriza, I, Mohd Zahari, M. S., Shazali, M. S. \& Rosmaliza, M. (2012). Acculturation, Foodways and Malaysian Food Identity. Current Issues in Hospitality and Tourism Research and Innovation.

[12] Ohiokpehai, O. (2003). Promoting the Nutritional Goodness of Traditional Food Products. Pakistan Journal of Nutrition, 2(4), 267-270.

[13] Quah, S. R. (2008). Home and Kin: Families in Asia. Singapore: Times Academic Press.

[14] Stringer, R. E. (2009). The domestic foodscape of young low-income women in Montreal: Cooking practices in the context of an increasingly processed food supply. Health Education and Behaviour, 37(2), 211-226. 